\title{
Diagnosis and prescription for Cercospora leaf spot of chilli
}

\author{
M. S. Islam ${ }^{1^{*}}$, K. Fatema ${ }^{2}$, K. M. B. Alam ${ }^{3}$ and M. B. Meah ${ }^{4}$ \\ ${ }^{1}$ Sher-e-Bangla Agricultural University, Dhaka-1207, ${ }^{2}$ D-3, Chandona Bhaban, Sher-e-Bangla Agricultural University, \\ Dhaka-1207. ${ }^{3}$ Department of Agricultural Studies, Sitakund College, Chittagong, ${ }^{4}$ Department of Plant Pathology, \\ Bangladesh Agricultural University, Mymensingh-2202, Bangladesh, *E-Mail: islamshihab@yahoo.com
}

\begin{abstract}
The experiments were carried out during 2009 to 2013 on diagnosis and prescriptions for management of Cercospora leaf spot of chilli. The studies were undertaken in 250 grower's field of five upazillas viz. Mymensingh sadar, Kushtia sadar, Kumarkhali, Chandina and Sher-e-Bangla Nagar. The highest disease incidence (38.6\%) and severity (17.4\%) of Cercospora leaf spot of chilli was recorded. Cercospora capsici produced leaf spot of chilli. The prescription given by Plant Disease Diagnostic Clinic (PDDC) was effective in the farmer's field against the disease. Cercospora leaf spot of chilli is the most important diseases of spices in Bangladesh as the diseases significantly reduce the quality and yield. Prescription was Bavistin-50 DF @ 1g/l sprayed 4 times at 15 days interval for management of Cercospora leaf spot of chilli. The practices reduced the incidence by $72.82 \%$, severity by $65.60 \%$. The yield increased by $35.11 \%$. Benefit cost ratio (BCR) was 3.34 .
\end{abstract}

Keywords: Diagnosis, Prescription, Leaf spot, Chilli

\section{Introduction}

Plant Disease Diagnosis Model which simulation for evaluation of a plant disease during the season give important information to assess the seriousness of the situation. The activity precedes the choice of an appropriate action to be implemented for reducing the economic damage. Having effective models is a critical issue in modern agriculture especially with low environmental impact. Considerable effort has been given in study of models for the simulation of plant disease evolution. Pathology models, population and epidemiological models have been developed for several diseases (Janet, 2004). Chilli is one of the important spice crops in the world. It is also the most important spice crop in Bangladesh under the family of Solanaceae having nutritive value especially rich in vitamin-C. Currently 16141.73 hectares of land is under chilli cultivation in Bangladesh where 21,000 metric tons yield is produced per annum in Kharif season. Where 105,000 tons of chilli was produced from 78346.45 hectares of land in Rabi season (BBS, 2012). This yield is very low compared to that of other chilli growing countries of the world. For the low yield of the crop, its annual production cannot meet the total requirement and as such large quantity is to be imported every year (Anonymous, 2008). There are many factors responsible for the low yield of the chilli crop in the country; fungal diseases play a vital role. Chilli is known to suffer from as many as 83 different diseases, of which fungi (Walker, 1952, Rangaswami, 1979) cause more than 40. Among the fungal diseases, Cercospora leaf spot of chilli is one of the major problems of chilli cultivation in Bangladesh (Meah and Khan, 1987). It is caused by Cercospora capsici luxuriantly less than $28^{\circ} \mathrm{C}$ temperature, $92 \%$ relative humidity and $\mathrm{pH} 5-6$. Below $90 \%$ relative humidity, the disease does not develop. The fungus survives in plant debris, primary infection coming from air-borne spores derived from it. The disease is more severe in wet weather than in dry weather and becomes destructive in high relative humidity (Cerkauskas, 2004). Cercospora capsici was shown to be consistently associated with leaf spot of chilli, reducing appreciably the photosynthetic activity of infected plants leading to losses in yield (Rangaswami, 1979). It is unquestionable that proper disease control measures can substantially improve the quality of fruit and significantly increase the yield. Various methods have been practiced to control this disease. In cultural practices like inter-cropping, adjustment of time of sowing, rouging etc. physical methods like seed selection, hot water treatment, solar heat etc. and use of chemical treatment assumed to be useful for controlling the disease. However, when the disease incidence and severity increases, then the application of fungicide is necessary. Fungicide has been successfully used in controlling the disease and gave better results than any other management practices (Rangaswami, 1979). Some fungicides such as Bavistin-50 DF, Rovral-50 WP etc. have been found to give reasonable control of the disease in Bangladesh. Seed treatment with fungicides $\left(53^{\circ} \mathrm{C}, 10\right.$ minutes) reduced seedborne infection and higher seedlings vigour (Meah and Wick, 2006). Application of Bavistin-50 DF @ $0.02 \%$ three times sprays with 10 days intervals are most effective to control of Cercospora leaf spot of chilli (Meah, 2006). The objectives of the present studies were to simulate model for diagnosis of Cercospora leaf spot of chilli and to formulate model prescription for the disease based on proper diagnosis and management options. 


\section{Materials and Methods}

Experiments were conducted at the IPM-laboratory and Experimental Field of the Department of Plant Pathology, Bangladesh Agricultural University (BAU), Mymensingh and Plant Pathology Laboratory, Department of Plant Pathology, Sher-e-Bangla Agricultural University (SAU), Sher-e-Bangla Nagar, Dhaka, Bangladesh during 2009-2013. Survey on the incidence and severity of Cercospora leaf spot of chilli was done during Rabi 2009-2010. Four Districts, Dhaka, Mymensingh, Kushtia and Comilla were the study areas. Five Villages from each of five Upazillas were selected from four districts under five upazillas of major chilli growing areas of Bangladesh. Ten (10) farmers were selected from each village. Data on reveal of plants infected and fruit, and leaf/fruit area affected were recorded. Incidence and severity of the disease was calculated. Control measures adopted by the farmers were also recorded. Four visits were made during November-March. Soil pH, temperature, soil moisture, air temperature, air moisture (RH \%) and rainfall were noted. LAD (leaf area diseased) and FAD (fruit area diseased) was measured by eye estimation. Percent disease severity (DS) was measured by using the following formula (Islam, 2009).

$\%$ Disease severity (leaf) $=\frac{\% \text { infected leaf area }}{\text { Total leaf area inspected }} \times 100$
$\%$ Disease severity (fruit) $=\frac{\% \text { infected fruit area }}{\text { Total fruit area inspected }} \times 100$

Diseases samples submitted by farmers were studied in the PDDC and prescriptions were given. The diseased samples brought by the farmers were washed in running tap water to make free off dust and sand. The infected portion along with the healthy part of the leaves was cut into small pieces $(1-1.5 \mathrm{~cm})$ and surface sterilized with $10 \%$ Clorox solution for one minute. Pieces were washed in sterilized water thrice and placed on filter paper to remove excess water adhering to the surface. Five pieces (inocula) were placed in potato dextrose agar in glass peptidases aseptically maintaining equal distances. The plates were incubated at $25 \pm 1^{\circ} \mathrm{C}$ under 12 hour NUV light and 12 hour darkness (ISTA, 2000). Temporary slides were prepared and observed under a compound microscope. The pathogenic leaf was identified on the basis of characterises of conidiophores and conidia (Ellis and Gibson, 1975). Pure culture of the fungus Cercospora capsici was prepared following single spore technique PDA 10-12 days old pure culture was used in subsequent studies multi pried.

Information collected from the field, and PDDC were interpreted conclusion drawn on the common practices for the management of these diseases. Simulation of the practices was done on the field on an experiment. Seedlings were raised on pot soil prepared by mixing soil, sand and well decomposed cow dung in the proportion of 2: 1: 1 . The pot soil was sterilized by formalin (4\%) @ $200 \mathrm{ml} / \mathrm{cft}$ soil, and used after 7 days of weathering (Dasgupta, 1988). Healthy seedlings of 28 days old were transplanted in the afternoon followed by watering. Twenty four healthy seedlings were transplanted in each subplot of each block, maintaining plant to plant distance $45 \mathrm{~cm}$ and line to line distance $65 \mathrm{~cm}$ and block to block 2 metre (Islam, 2006). The experiment was laid out in a Randomized Complete Block Design (RCBD) with four replications. The following treatments were applied four times at 15 days intervals

$$
\begin{aligned}
& \mathrm{T}_{1}=\text { Control } \\
& \mathrm{T}_{2}=\text { Rovral-50 WP @ 1g/l } \\
& \mathrm{T}_{3}=\text { Rovral-50 WP @ 2g/l }
\end{aligned}
$$

$$
\begin{aligned}
& \mathrm{T}_{4=} \text { Bavistin- DF @ 0.5g/l } \\
& \mathrm{T}_{5}=\text { Bavistin-DF @ } 1 \mathrm{~g} / \mathrm{l} \\
& \mathrm{T}_{6=} \text { (Rovral @ 1g/l + Bavistin @ 0.5g/l) }
\end{aligned}
$$

Solution fungicide was prepared by taking required amount of fungicides in the tap water and mixed thoroughly and applied as foliar spray by Knapsack hand sprayer. Rovral-50 WP was applied @ 0.1 and $0.2 \%$ and Bavistin-DF was applied @ 0.05 and $0.1 \%$ concentration. Three best treatments were selected for further study. Data were recorded the following parameters-

i. Disease incidence/Severity (\%) ii. Yield/Yield loss and iii. BCR

Results obtained through field trials were computed, analyzed and interpreted. The best two results were selected and used for the construction of specific disease diagnostic model. Construction of the model was based on the disease management practices: IPM approach, pesticide(s), stage of the crop for intervention, frequency of the application for crop protection measures. 
Benefit cost ratios (BCR): Cost of application of integrated approaches for management of Cercospora leaf spot of chilli was done based on the current market price of input, rate of hiring labor and agricultural machineries. Price of the field product was determined on the basis of current market value. Estimation of Cost Benefit Ratio (BCR) was done according to Gittinger (1982) and Islam (2009) using the following formula:

$$
\text { Benefit Cost Ratio }(B C R)=\frac{\text { Grossreturn }(T K / h .)}{\text { Totalcost of production }(T K / h .)}
$$

Compilation and analysis of the survey and experimental data were done by the computer MSTAT (C) software program following the statistical procedures (Gomez and Gomez, 1984).

\section{Results and Discussion}

Disease incidence cercospora leaf spot of varied with different locations, soil texture and environmental factors viz. soil $\mathrm{pH}$, soil moister, soil temperature, air temperature, Rainfall and $\mathrm{RH} \%$ (\% relative humidity). The highest disease incidence (38.6\%) and severity (17.4\%) were recorded in Marichar Char and SAU campus. It's were observed in loam and sandy loam soil as shown in Table 1.

Table 1. Incidence and severity of Cercospora leaf spot of chilli in selected locations of Bangladesh (pooled for the years 2009-2010)

\begin{tabular}{l|l|c|c}
\hline Locations & Soil texture & \multicolumn{2}{c}{ Leaf spot } \\
\cline { 3 - 4 } & & Incidence (\%) & Severity (\%) \\
\hline Marichar Char, Mymensingh & Loam & $38.6 \mathrm{a}$ & $15.2 \mathrm{~b}$ \\
SAU Campus, Dhaka & Sandy loam & $32.4 \mathrm{~b}$ & $17.4 \mathrm{a}$ \\
Kushtia Sadar, Kushtia & Clay & $34.7 \mathrm{~b}$ & $14.7 \mathrm{c}$ \\
Kumarkhali, Kushtia & Silty clay & $32.9 \mathrm{~b}$ & $15.0 \mathrm{bc}$ \\
Chandina, Comilla & Clay & $33.8 \mathrm{~b}$ & $13.2 \mathrm{~d}$ \\
\hline LSD $(P<0.01)$ & & 3.815 & 0.424 \\
CV $(\%)$ & & 4.05 & 1.02 \\
\hline
\end{tabular}

Means followed by the same letter(s) in columns did not significantly at $1 \%$ level by DMRT.

Fifty eight samples submitted by farmers from the small and medium commercial farms from five different upazillas of Bangladesh were inspected and five prescriptions were given. The disease incidence and severity of Cercospora leaf spot of chilli (cv. Bindhu) in response to different prescriptions used were observed in five locations of Bangladesh. The incidences and severity of cercospora leaf spot of chilli varied significantly in respect of different prescriptions by the farmers. Bavistin-DF @ $1 \mathrm{~g} / \mathrm{l}$ sprayed 3 times at 12 days interval was effective prescription. The lowest incidence (33.5\%) and severity (15.5\%) were recorded at Chandina and Kushtia Sadar where Bavistin-DF was applied @ 1mg/l. Promising effect in reducing incidence and severity of Cercospora leaf spot of chilli was observed also in Marichar Char, Mymensingh where Bavistin-DF was applied @ $0.5 \mathrm{~g} / \mathrm{l}$. Rovral-50 WP used @ 2g/l 3 times sprayed at 12 days interval was effective. The performance of Dithane M-45 was satisfactory as shown in Figure 1 and Table 2.

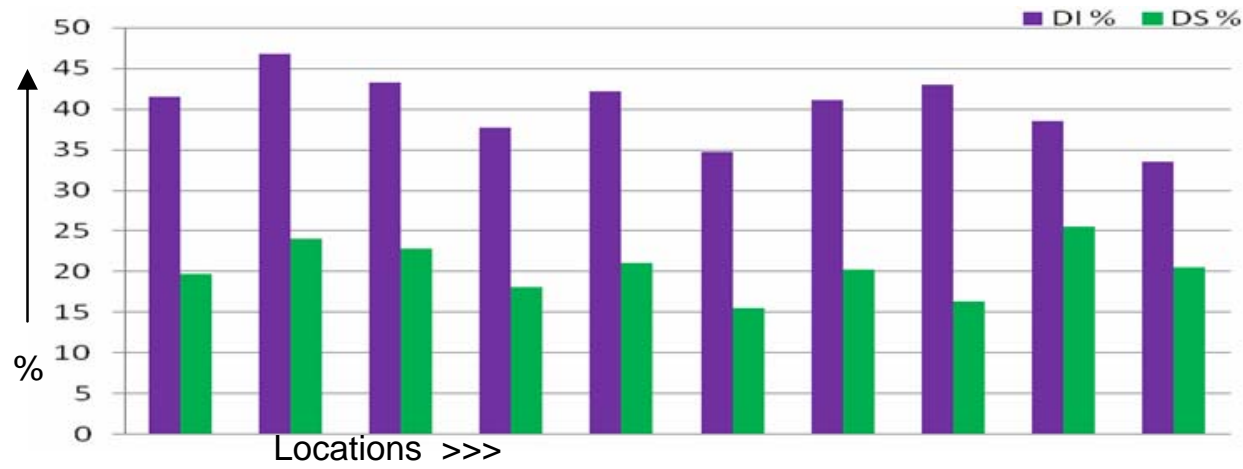

Fig. 1. Incidence and severity of Cercospora leaf spot of chilli (cv. Bindhu) due to prescriptions used for controlling the disease 
Table 2. Effect of management practices recommended by PDDC adopted by the farmers against Cercospora leaf spot of chilli

\begin{tabular}{|c|c|c|c|c|c|c|c|c|}
\hline \multirow[t]{2}{*}{ Fungicides } & \multicolumn{2}{|c|}{ Incidence (\%) } & \multirow[t]{2}{*}{ Average } & \multicolumn{2}{|c|}{ \% DI under control } & \multirow[t]{2}{*}{ Means } & \multicolumn{2}{|c|}{$\begin{array}{c}\% \text { DI decreased over } \\
\text { control }\end{array}$} \\
\hline & $1^{\text {st }}$ year & $2^{\text {nd }}$ year & & $1^{\text {st }}$ year & $2^{\text {nd }}$ year & & $1^{\text {st }}$ year & $2^{\text {nd }}$ year \\
\hline Bavistin-DF & 32.4 & 33.5 & 32.9 & 38.6 & 46.7 & 42.6 & 16.5 & 28.2 \\
\hline Rovral-50WP & 32.9 & 38.5 & 35.7 & 34.7 & 46.7 & 40.7 & 5.1 & 17.5 \\
\hline Dithane-M-45 & 33.8 & 42.2 & 38.0 & 38.6 & 46.7 & 42.6 & 12.4 & 9.6 \\
\hline
\end{tabular}

Symptoms: Dark brown spots with ashy centre were observed on the leaf surface (Photo 1). On fruits, the lesions were deep brown enlarged mainly on ripening fruits (Photo 2). The fungus formed brown mycelial growth on PDA (Photo 3). Under microscope, cells structures of Cercospora capsici were observed (Photo 4).

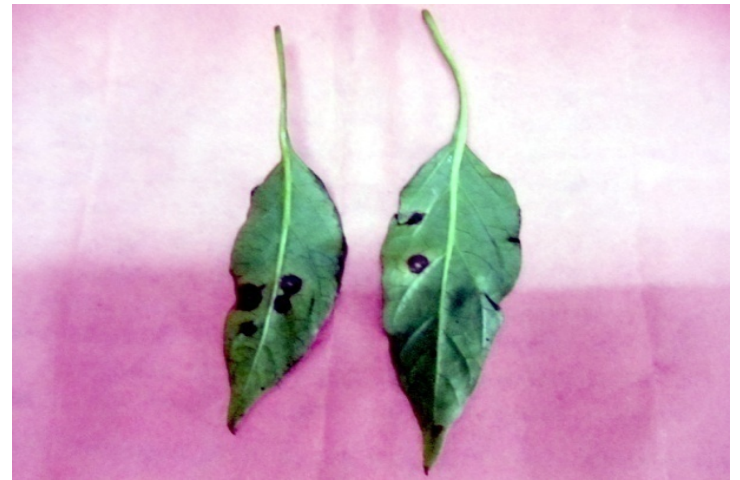

Photo 1. Typical Symptoms of Cercospora leaf spot of Chilli leaves

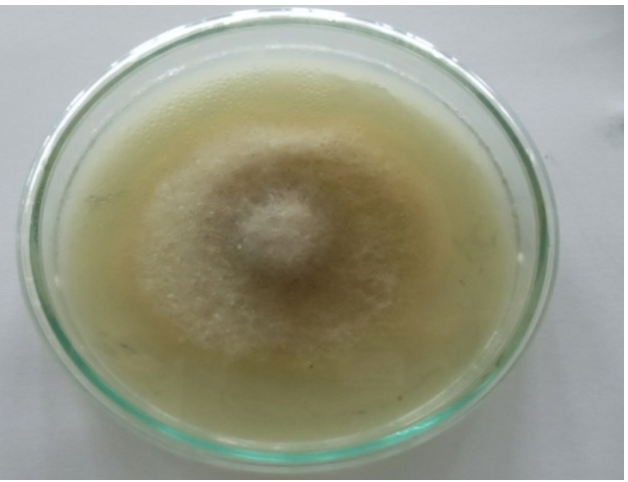

Photo 3. Five days old culture of Cercospora capsici grown on PDA media.

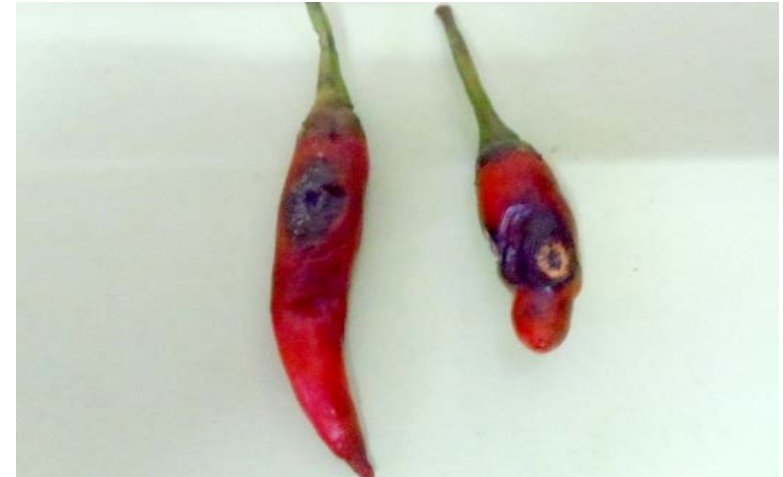

Photo 2. Typical Symptoms of Cercospora leaf spot of Chilli fruit

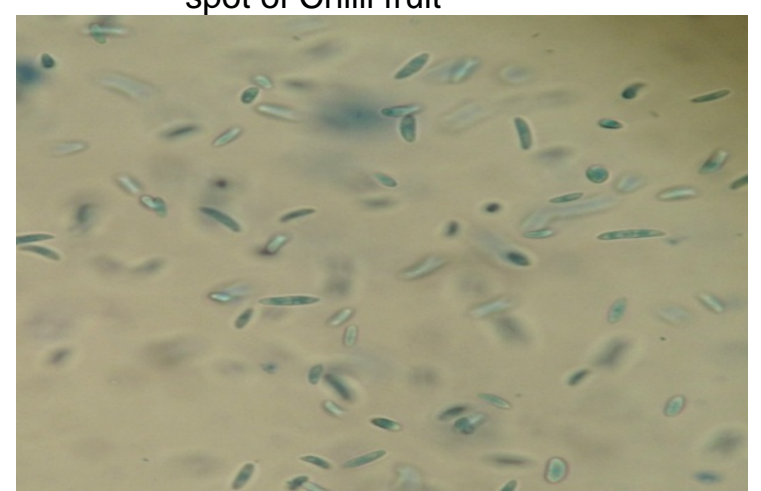

Photo 4. 10X times magnified, Cells of C. capsici under compound microscope.

The effect of the treatments was not significant at 65 DAT. At 80 and 95 DAT, the effects of all treatments were statistically insignificance but differed from control. At 110 DAT, the lowest disease incidence (14.25\%) was recorded in case of $\mathrm{T}_{5}$ (Bavistin-DF @ $1 \mathrm{~g} / \mathrm{l}$ ) that was statistically similar with $\mathrm{T}_{3}$ (Rovral-50 WP @ $2 \mathrm{~g} / \mathrm{l}$ ). The highest incidence $(52.50 \%)$ was recorded in case of control treatment. $\mathrm{T}_{5}$ (Bavistin-DF @ $1 \mathrm{~g} / \mathrm{l})$ was superior $(72.82 \%)$ to others.

Treatment effects on the disease severity of Cercospora leaf spot of Chilli are presented in Table 4. At 95 DAT, the lowest severity (16.25\%) was found in case of $T_{5}$ was statistically similar with $T_{3}$ (Rovral-50 WP @ 2g/l). The highest severity (36.50\%) was recorded in control plot. At 110 DAT, the performances of the treatments were similar to that at 95 DAT. $T_{5}$ (Bavistin-DF @ $1 \mathrm{~g} / \mathrm{l}$ ) was superior $(65.60 \%)$ in reducing the severity of the disease. 
Table 3. Incidence of Cercospora leaf spot of Chilli (cv. Bindhu) in response to different treatments at different days after transplanting (DAT)

\begin{tabular}{l|c|c|c|c|c}
\hline \multirow{2}{*}{ Treatments } & \multicolumn{4}{c|}{ Incidence (\%) } & Reduction (\%) \\
\cline { 2 - 5 } & 65DAT & 80 DAT & 95 DAT & 110 DAT & \\
\hline $\mathrm{T}_{1}=$ Control & 12.25 & $21.25 \mathrm{a}$ & $33.00 \mathrm{a}$ & $52.50 \mathrm{a}$ & --- \\
$\mathrm{T}_{2}=$ Rovral-50 WP @ 1g/l & 12.00 & $16.75 \mathrm{abc}$ & $23.75 \mathrm{~b}$ & $28.25 \mathrm{~b}$ & 46.19 \\
$\mathrm{~T}_{3}$ = Rovral-50 WP @ 2g/l & 12.25 & $14.25 \mathrm{bc}$ & $16.50 \mathrm{bc}$ & $17.75 \mathrm{c}$ & 66.19 \\
$\mathrm{~T}_{4=}$ Bavistin- DF @ 0.5g/l & 12.25 & $19.25 \mathrm{bc}$ & $23.75 \mathrm{~b}$ & $27.00 \mathrm{~b}$ & 48.57 \\
$\mathrm{~T}_{5}=$ Bavistin-DF @ 1g/l & 11.25 & $13.00 \mathrm{c}$ & $13.50 \mathrm{c}$ & $14.25 \mathrm{c}$ & 72.82 \\
$\mathrm{~T}_{6=}$ (Rovral @ 1g/l + Bavistin @ 0.5g/l) & 12.50 & $16.75 \mathrm{abc}$ & $23.00 \mathrm{~b}$ & $25.00 \mathrm{~b}$ & 52.38 \\
\hline LSD (0.01) & $\mathrm{NS}$ & 5.45 & 7.84 & 6.34 & --- \\
$\mathrm{CV}(\%)$ & 19.56 & 15.53 & 16.91 & 11.09 & --- \\
\hline
\end{tabular}

NS = Not significant, Means followed by the same letter (s) in a columns did not significantly at $1 \%$ level by DMRT.

Table 4. Effect of fungicides on LAD (\%) of Cercospora leaf spot of chilli

\begin{tabular}{l|c|c|c|c|c}
\hline \multirow{2}{*}{ Treatments } & \multicolumn{4}{c|}{ Leaf Area Disease (LAD \%) } & \multirow{2}{*}{ Reduction (\%) } \\
\cline { 2 - 5 } & 65 DAT & 80 DAT & 95 DAT & 110 DAT & \\
\hline $\mathrm{T}_{1}=$ Control & 14.25 & $25.00 \mathrm{a}$ & $36.50 \mathrm{a}$ & $47.25 \mathrm{a}$ & --- \\
$\mathrm{T}_{2}=$ Rovral-50 WP @ 1g/l & 13.50 & $18.25 \mathrm{~b}$ & $23.00 \mathrm{~b}$ & $27.25 \mathrm{~b}$ & 42.32 \\
$\mathrm{~T}_{3}$ = Rovral-50 WP @ 2g/l & 13.50 & $16.00 \mathrm{~b}$ & $17.25 \mathrm{c}$ & $18.75 \mathrm{c}$ & 60.31 \\
$\mathrm{~T}_{4}$ Bavistin- DF @ 0.5g/l & 13.75 & $18.00 \mathrm{~b}$ & $23.75 \mathrm{~b}$ & $26.00 \mathrm{~b}$ & 44.97 \\
$\mathrm{~T}_{5}=$ Bavistin-DF @ 1g/l & 13.75 & $14.75 \mathrm{~b}$ & $16.25 \mathrm{c}$ & $16.25 \mathrm{c}$ & 65.60 \\
$\mathrm{~T}_{6=}$ (Rovral @ 1g/l + Bavistin@ 0.5g/l & 14.25 & $18.75 \mathrm{~b}$ & $23.00 \mathrm{~b}$ & $27.00 \mathrm{~b}$ & 42.85 \\
\hline LSD ( 0.01) & $\mathrm{NS}$ & 5.28 & 5.18 & 6.69 & -- \\
CV \% & 26.40 & 13.74 & 10.68 & 11.86 & -- \\
\hline
\end{tabular}

NS = Not significant, Means followed by the same letter (s) in a columns did not significantly at $1 \%$ level by DMRT.

Rovral-50 WP and Bavistin-DF 1g/l showed increased number of spot per leaf, number of spot per fruit, fruit area diseased and fruit infection Table 5.

Table 5. Effect of different treatments on severity of leaf spot and yield

\begin{tabular}{|c|c|c|c|c|c|}
\hline \multirow[t]{2}{*}{ Treatments } & \multicolumn{5}{|c|}{ Severity (\%) } \\
\hline & $\begin{array}{l}\text { No. of spots } \\
\text { /leaf }\end{array}$ & $\begin{array}{c}\text { No. of } \\
\text { spots/fruit }\end{array}$ & $\begin{array}{c}\text { No. of } \\
\text { fruit/plant }\end{array}$ & FAD \% & $\mathrm{FI} \%$ \\
\hline $\mathrm{T}_{1}=$ Control & $22.2 a$ & $14.0 \mathrm{a}$ & $151.3 d$ & $80.0 a$ & $53.7 \mathrm{a}$ \\
\hline $\mathrm{T}_{2}=$ Rovral-50 WP @ 1g/l & $13.2 b$ & $9.0 \mathrm{~b}$ & 267.0c & $26.7 b$ & $19.7 b$ \\
\hline $\mathrm{T}_{3=}$ Rovral-50 WP @ 2g/l & $3.2 \mathrm{c}$ & $2.5 \mathrm{c}$ & $330.0 \mathrm{~b}$ & $9.2 d$ & 7.7c \\
\hline T4=Bavistin- DF @ 0.5g/l & $12.7 \mathrm{~b}$ & $9.2 b$ & $264.8 \mathrm{c}$ & $26.0 \mathrm{~b}$ & $20.0 b$ \\
\hline $\mathrm{T}_{5}=$ Bavistin-DF @ 1g/l & $1.5 c$ & $2.0 \mathrm{c}$ & $341.0 a$ & $2.7 e$ & $2.7 \mathrm{c}$ \\
\hline $\mathrm{T}_{6=}($ Rovral @ 1g/l + Bavistin@ 0.5g/l & $11.2 \mathrm{~b}$ & $6.5 b$ & $263.0 \mathrm{c}$ & $19.0 \mathrm{c}$ & $18.5 b$ \\
\hline LSD ( 0.01) & 3.7 & 2.7 & 9.59 & 5.8 & 5.9 \\
\hline $\mathrm{CV} \%$ & 16.6 & 18.3 & 1.71 & 10.3 & 13.9 \\
\hline
\end{tabular}

$\mathrm{FI}=$ (Fruit infection), NS = Not significant, Means followed by the same letter (s) in a columns did not significantly at $1 \%$ level by DMRT.

The performance of (Bavistin-DF @ 0.5g/l), (Rovral-50 WP + Bavistin-DF and T2 (Bavistin-DF @ 1g/l) regarding yield contributing characters were moderate where yield increased by $25.0 \%, 13.78 \%$ and $11.67 \%$ were over control as shown in Table 6. 
Table 6. Benefit Cost Ratio (BCR) of different management practices for Cercospora leaf spot of Chilli (cv. Bindhu)

\begin{tabular}{l|c|c|c|c|c}
\hline Treatments Combination & $\begin{array}{c}\text { Yield } \\
\text { t/ha }\end{array}$ & $\begin{array}{c}\text { Gross return } \\
\text { (Taka) }\end{array}$ & $\begin{array}{c}\text { Cost } \\
\text { (Taka) }\end{array}$ & $\begin{array}{c}\text { Return } \\
\text { (Taka) }\end{array}$ & BCR \\
\hline $\mathrm{T}_{1}=$ Control & 10.8 & 217600 & 79500 & 138100 & 2.73 \\
$\mathrm{~T}_{2}=$ Rovral-50 WP @ 1g/l & 12.1 & 243000 & 84180 & 158820 & 2.88 \\
$\mathrm{~T}_{3}=$ Rovral-50 WP @ 2g/l & 14.1 & 283600 & 86300 & 197300 & 3.28 \\
$\mathrm{~T}_{4=}$ Bavistin- DF @ 0.5g/l & 13.6 & 272000 & 85740 & 1885574 & 3.17 \\
$\mathrm{~T}_{5}=$ Bavistin-DF @ 1g/l & 14.7 & 294000 & 87860 & 207528 & 3.34 \\
$\mathrm{~T}_{6}$ (Rovral @ 1g/l + Bavistin@ 0.5g/l & 12.3 & 247600 & 88420 & 159180 & 2.80 \\
\hline
\end{tabular}

Green chilli 20,000 TK/Ton, Calculated on basis of market price of 2013.

Two best economic management practices against leaf spot of chilli was finally selected presented in Table 7.

Table 7. Compilation of economically effective management practices

\begin{tabular}{|c|c|c|c|}
\hline \multirow[t]{2}{*}{ Effective management practices } & \multicolumn{2}{|c|}{ Reduction } & \multirow[t]{2}{*}{$\mathrm{BCR}$} \\
\hline & DI \% & DS \% & \\
\hline $\begin{array}{l}\text { i. Bavistin-DF @ 1g/l sprayed } 4 \text { times at } 15 \text { days interval } \\
\text { ii. Rovral-50 WP @ } 2 \mathrm{~g} / \mathrm{l} \text { sprayed } 4 \text { times at } 15 \text { days interval. }\end{array}$ & $\begin{array}{l}72.82 \\
66.19\end{array}$ & $\begin{array}{l}65.60 \\
60.31\end{array}$ & $\begin{array}{l}3.34 \\
3.28\end{array}$ \\
\hline
\end{tabular}

$\mathrm{DI}=$ Disease incidence, $\mathrm{DS}=$ Disease severity.

\section{Conclusion}

An epidemiological survey was carried out in selected regions of Bangladesh in order to estimate the incidence and severity of Cercospora leaf spot of chilli. Various strategies for controlling these diseases have been introduced over the years including soil disinfection, cultural practices and fungicide treatments but losses still occur. The effectiveness of these approaches is variable and short-lived. Moreover, fungicides of broad spectrum produce undesirable consequences on non-target organisms, environment and community health. The present study reveals that many farmers have adopted the management practices recommended by PDDC. Farmers have successfully applied PPDC's (Plant Pathology Diagnostic Clinic) prescriptions and have gained control of diseases resulting in a significant increased in yield. Bavistin-DF @ 1g/l sprayed 4 times at 15 days interval for controlling the disease.

\section{References}

Anonymous. 2008. Garlic tablet in plant disease control. A leaf let published by IPM-lab, Department of Plant Pathology. Bangladesh Agricultural University, Mymensingh-2202, Bangladesh.

BBS. 2012. Monthly Statistical Bulletin-Bangladesh 2012. Bangladesh Bureau of Statistics. Ministry of Planning, Government of the People's Republic of Bangladesh. Dhaka, Bangladesh. pp. 1-69.

Cerkauskas, R. 2004. Pepper Diseases: Cercospora Leaf Spot Published by AVRDC-The World Vegetable Center, Shanhua, Taiwan. pp. 741.

Dashgupta, M. 1988. Principles of Plant Pathology. Allied publisher private Ltd. New Delhi, India. pp. 700.

Ellis, M. B. and Gibson, I.A.S. 1975. Cochliobolus setariae (conidial state: Drechslera setariae). CMI Descriptions of pathogenic fungi and bacteria. pp. 473.

Gittinger, J. P. 1982. Economic Analysis of Agricultural Project. $2^{\text {nd }}$ Ed. The John Hopkins University Press, London, U K. pp. 61-63.

Gomez, K. A. and Gomez, A.A. 1984. Duncan's Multiple Range Test. Statistical Procedure for Agril. Res. $2^{\text {nd }}$. A Wiley Inter Science Publication, Johan and Sons, New Tork. pp. 202-215.

Islam, M. R. 2006. An integrated approach for management of Phomopsis blight and fruit rot of eggplant. PhD Dissertation Department of Plant Pathology, Bangladesh Agricultural University, Mymensingh, Bangladesh.

Islam, M. S. 2009. Management of Late Blight of Tomato. Sher-e-Bangla Agri. Uni. J., 2(2) 81-86.

ISTA. 2000. International Rules for Seed Testing. International Seed Testing Association. pp. 180.

Janet, C. B. 2004. California pest case; Disease Model Database, Statewide integrated pest management program. Agricultural and natural resources. pp. 64.

Meah, M. B. 2006. Plant disease diagnostic manual. Plant Disease Diagnostic Clinic. IPM-laboratory. Department of Plant Pathology, Bangladesh Agricultural University, Mymensingh. Bangladesh. pp. 6-11.

Meah, M. B. and Khan, A.A. 1987. Check list of fruit and vegetable diseases in Bangladesh. $1^{\text {st }}$ Edition, Department of Plant Pathology, Bangladesh Agricultural University, Mymensingh, Bangladesh. pp. 13

Meah, M. B. and Wick, .LR. 2006. Diagnostic plant pathology. Dept. of plant soil and insect sciences, University of Massachusetts. Amherst MA, USA. pp. 5-71.

Rangaswami, G. 1979. Diseases of vegetables. In: Diseases of crop plants in India. $2^{\text {nd }}$ Ed. McGraw Hill Book Company, New Delhi. pp. 345-347.

Walker, J. C. 1952. Diseases of vegetable crops. Inc. $1^{\text {st }}$ Ed. McGraw Hill Book Company. New York, USA. pp. 306-308. 